\title{
12. SHALLOW-WATER CARBONATES FROM SITE 384
}

Peter Rothe, Abteilung für Geologie am Geographischen Institut der Universität Mannheim, D-6800 Mannheim, Schloss, und Institut für Sedimentforschung der Universität Heidelberg, D-6900 Heidelberg, Im Neuenheimer Feld 234

\begin{abstract}
At Site 384, shallow water carbonates of upper Barremian and Albian age are overlain by Maestrichtian nannofossil chalk. Two to three meters of both limestones (mostly biomicrite and biomicrudite) and friable carbonate sand and gravel were recovered out of about 120 meters drilled.

The allochems within limestones include abundant rudists, other pelecypods, gastropods, foraminifers (orbitolines, miliolids, and others), ostracodes, bryozoans, corals, and red algae. Pellets, intraclasts, and rare carbonate rhombs were also found. Similar subrounded to subangular skeletals within the sand and gravel are micritized, the most extensively micritized particles being the best rounded ones.

Intraparticle sparry calcite has partly cemented molds which presumably have originated from leaching of aragonite. Fresh-water diagenesis is suggested by moldic porosity, stable isotope analysis, and the fact that the carbonates consist almost entirely of low magnesian calcite. Rare dolomite and intraclasts suggest episodically intertidal to supratidal conditions.

The overall depositional environment was most probably a shallow bank with biostromes interspersed with protected quiet water areas. On the basis of the diagenetic features, the area was emergent during the Cretaceous.
\end{abstract}

\section{INTRODUCTION}

Carbonates of shallow-water origin were drilled above basalt at Site 384 . They are overlain by and contain scarce intercalations of Cretaceous nannofossil chalk. The shallow-water material includes carbonate sand and gravel and limestone. Recovery in Cores 16 through 21, which constitute the entire sequence termed Unit 2 (see Site Report, Chapter 4), was extremely poor. From a cored interval of 202.2 to 324.8 meters a total of 2 to 3 meters was recovered; this is not a very accurate measure because most of the material consists of rock fragments that cannot be correctly arranged. None of the samples can be called undisturbed. Samples were studied in thin section, stained thin section, by X-ray diffraction, and by stable isotope analysis (see Rothe and Hoefs, this volume).

\section{COMPOSITION AND AGE}

The samples obtained are almost entirely pure white calcium carbonate with a few intercalated lime mud layers that are slightly more yellowish and contain some clay. The carbonates include unconsolidated gravel-size skeletal material and limestone debris, and limestones, most of which are biomicrudites according to the classification of Folk (1962). Skeletal material includes large mollusks, both pelecypods and gastro- pods, among which the presence of rudists merits special attention (caprinids and monopleurids were determined by Perkins, this volume). Mollusks seem the most common forms present, but echinoderms, several types of foraminifers, ostracodes, bryozoans, corals, and red algae were also found. Orbitolines are abundant (Plate 3, Figure 4; Plate 4, Figure 1) and deserve special mention. Palorbitolina lenticularis (Blumenbach) and Paleodictyoconus arabicus (Henson) were determined from the lowermost sample by Schroeder and Cherchi (this volume). The Orbitolina fauna indicates upper Barremian (Schroeder and Cherchi, this volume), whereas the rudists suggest Albian for the shallow-water carbonates (Perkins, this volume). Among the foraminifers, miliolids are also common.

Preservation of most of the fossils is poor. The rudists as well as other mollusks occur mostly as steinkerns (Plate 1, Figure 3) or molds, (Plate 1, Figures 2, 4) and only very few shell fragments are sufficiently preserved for paleontological determination.

The non-skeletal allochems include pellets, intraclasts, and scarce carbonate rhombs.

\section{DESCRIPTION OF CARBONATES}

The carbonates can be grouped into three different types: (1) limestones, (2) skeletal sand, and (3) skeletal gravel and limestone debris. 


\section{Limestones}

Sorting of the allochems is very poor; allochems of different grain size $(<1 \mathrm{~mm}$ to $>7 \mathrm{~mm})$ occur in a micritic matrix of the most abundant types. Large pelecypods and gastropods up to a few $\mathrm{cm}$ in size occur. Random orientation of particles is obvious. Biomicrudite and intrabiosparrudite can be distinguished on the basis of composition.

Skeletal materials within the limestones represent different stages of preservation. Allochems include mollusks (rudists, other pelecypods, gastropods), foraminifers, ostracodes, echinoderms, bryozoans, corals, and red algae. Mollusk shells that we presume to have been originally aragonitic are mostly leached, and are now molds or steinkerns. Some particles still display deepreaching micritization rims (Plate 2, Figure 1). Both echinoderm fragments and miliolid foraminifers are usually unleached.

\section{Carbonate Sand}

Carbonate sand was found in the uppermost part of Core 16 and in the core catcher. Similar sand found in the uppermost part of Core 20, together with lumps of limestone, is probably downhole contamination. Average grain size is 0.2 to $0.3 \mathrm{~mm}$, sorting is moderate, most grains are subrounded and rounded, but some grains are still angular (Plate 4 , Figure 3 ). The grains are mostly unidentifiable, severely micritized skeletal fragments. Some grains of better preservation are mollusk fragments, and foraminifers and echinoid spines, which are usually easily recognized in thin section (Plate 5, Figure 1).

If the reworking process responsible for the sorting commenced after micritization, the stage of micritization of individual grains would have influenced the resulting assemblage. Totally micritized grains would have been the least resistant and thus the smallest and best rounded; less micritized grains such as some of the mollusk remainders would be more angular and larger.

\section{Skeletal Material and Rock Debris of Gravel Size}

Within the core catcher of Core 20 and Core 21, Section 1, sediments of "salt and pepper" appearance were found; particle size is in the range of 2 to $10 \mathrm{~mm}$. They consist of light gray and white limestone rubble, dark blue-green rock from the underlying limestone/ basalt contact, and skeletal debris consisting primarily of mollusks, but also containing echinoid spines. Orbitolines, both light gray and white, are common in this gravel (Plate 1, Figures 5, 6).

Most grains are subangular to subrounded, but angular as well as rounded grains also occur. One possible origin for at least a small part of this sediment is by brecciation during drilling. The underlying light gray biomicrite contains abundant orbitolines (Plate 4, Figure 1); this rock is rather soft compared to the pure white limestones; thus, the fossils may have been selectively disintegrated by the grinding of the bit.

$\mathrm{X}$-ray diffraction indicates both the limestones and the unconsolidated sediments to be low magnesian cal- cite. Dolomite is uncommon and was seen only in stained thin sections of limestones from Cores 16 and 20. It occurs as small patches (Plate 3, Figure 2). Miliolid foraminifers also seem dolomitized. However, differences in staining with Alizarin Red-S may be due partly to grain size effects. The very fine grained carbonate of the miliolids may not have been stained, leading to our suggestion of dolomite. Although staining did not produce any positive results, it cannot be stated with certainty that no aragonite or high magnesian calcite of skeletal origin is preserved; some very small amounts are possibly still present. At least some echinoderm particles show uniform optical extinction and may still consist of the primary skeletal carbonate.

\section{PRIMARY DEPOSITIONAL ENVIRONMENT}

Interpretation of the original depositional environment is based on the paleoecology of the fossils and an actualistic comparison with sedimentological conditions in recent carbonate environments.

The rudists were suitable for paleoecological interpretation. Perkins (this volume) attributed shallow-water bank environments "no deeper than a few tens of feet" to caprinid rudists from Core 20, and a probable very shallow restricted environment to the monopleurid rudists from Core 16. Caprinid rudists are usually attributed to a reef facies (see Griffith et al., 1969). Orbitolines are found in reef facies and also in neritic environments (Rey 1973), and corals, echinoids (spines abundant, Plate 1, Figure 7), bryozoans, the large gastropods (Nerinea?, Plate 1, Figure 2), ostracodes, and the miliolid foraminifers all point to formation in a shallow marine environment. Miliolids are regarded the diagnostic foraminifers in restricted mud flat environments (Griffith et al., 1969).

Interpretation of the depositional environment by sedimentological criteria is based on the limestone types; preponderance of micritic rock types points to quiet, low energy environments. This is further supported by the fact that most of the skeletal debris, if preserved at all, is intensely micritized. Micritization within recent carbonate environments is common in very shallow warm water. The classical Bimini Lagoon (Bathurst, 1966) would be a probable counterpart. Pellets which form locally important constituents within the biomicrites, belong to the same environment. Some of the orbitolines are slightly rounded (Schroeder and Cherchi, this volume) and this can be referred to a reworking process that probably took place within the environment in which these organisms lived.

The carbonate sand on the other hand requires a little more agitated water. A certain amount of sorting has occurred, but the material was apparently not exposed for very long to such conditions, since rounding is still incomplete. A shallow bank at maximum a few meters deep seems the probable environment for the formation of such carbonate sand. No proof of a truly high-energy reefal environment is evident, though at least the caprinid rudists point to such an environment. The most probable overall environment for the Site 384 shallow-water carbonates may have been a shal- 
low shelf bank with biostromes and protected quietwater areas between. If it should ever be shown that a reef existed nearby, the drill site would then represent a back-reef environment.

\section{DIAGENESIS OF THE CARBONATES}

Both early and late diagenesis can be recognized in the samples, although "late" does not necessarily indicate that much time had passed between the two stages. Early diagenetic features include micritization (Bathurst, 1966) of skeletal fragments prior to their lithification and also some possible dolomitization; a probably soft protodolomite as known from the classical Recent Florida Bay and Bahama Bank environments (Shinn, 1964; Ginsburg, 1964; Shinn et al., 1965) may be assumed. Slight lithification of lime mud, which influenced subsequent formation of intraclasts, some of flat pebble shape, could also be regarded as an early diagenetic process. Micritization is evident for skeletal fragments that can still be recognized in outline; shell structures, however, are in most cases completely destroyed. Some larger skeletal grains expose micritic envelopes, but their internal parts have not been affected.

Dolomitization was suggested by stained thin sections only. Small patches of dolomicrite occur within micritic limestone, and miliolid foraminifers seem also dolomitized as suggested by the fact that they were not stained by Alizarin Red-S; their presumed original shell carbonate is high-magnesian calcite, and this would be a reasonable precursor for dolomite formation. Too little dolomite is present to appear in the $\mathrm{X}$-ray diagrams, however.

Carbonate cements within the limestones are almost entirely restricted to intraparticle cements within shell molds and small chambers of foraminifers. The primary shell carbonate was leached prior to cementation; thus, the formation of sparry calcite within the shell molds must be regarded a late diagenetic phenomenon.

In comparison with many recent carbonate environments of warmer climates it can be reasonably assumed that most of the primary carbonate was aragonite and high-magnesian calcite. Aragonite-calcite transformation is also required for most of the Site 384 shallow-water carbonates. The leached mollusk shells, now molds or molds filled with sparry calcite, indicate that at least part of the rock had passed through a solution phase.

The filling with low-magnesian calcite spar is here regarded a late diagenetic process. Since aragonite is stable at seawater conditions, its dissolution can only be explained by the influence of meteoric water. Prior to leaching of aragonite, the skeletal grains, together with their micritic matrix, must have been lithified to become limestone. Some of the rock has still abundant open pore space from leached skeletal grains ("moldic porosity"), whereas in other samples these molds have been cemented by sparry calcite. Nothing can be said as to how much time had passed between formation of the carbonates and their final diagenetic stages. Studies of recent environments have shown that time is not an important factor if the chemical requirements for carbonate transformation are met. The most prominent example is hard limestones of beach rock formation that contain Coca-Cola bottles (Friedman, oral communication).

Formation of moldic porosity as mentioned above indicates a supratidal environment more elevated than the low supratidal stage required for dolomitization. Rain water could then have percolated through the carbonates emerging from the seawater regime, and cause the diagenetic changes observed.

Such influence of meteoric water is, besides the fact of abundant moldic porosity, further supported by the isotopic composition of the carbonates. They are enriched in light oxygen, $\delta^{18} 0$ data ranging from -0.7 to -3.1 relative to PDB (Rothe and Hoefs, this volume). Interpretation of these data should reflect the composition of rain water which caused the "late" diagenetic alteration of the carbonates. Since oxygen isotopic composition of rain water varies with latitude (Dansgaard, 1964) and is also dependant on worldwide average temperature, reasonable $\delta^{18} 0$ values of about -5 or even -3 (assuming slightly warmer temperatures during the Cretaceous) are suggested (Rothe and Hoefs, this volume). The values found from the Site 384 shallow-water carbonates indicate that these rocks have undergone almost complete fresh-water diagenesis. Regarding even the poor recovery, the thickness of the entire shallow-water sequence might reasonábly be assumed to be the 125 meters drilled. Fresh-water diagenesis could have affected this entire pile of rock, in which case the area must have been exposed subaerially for a rather long time. A more reasonable explanation would be that the carbonates were episodically influenced by percolating fresh water during periods of high supratidal exposure; such periods may have been repeated several times, but without a complete section this is also speculation; it might be suggested, however, on the basis of diagenetic features and the fact that carbonate formation took place in very shallow water, that water depth during deposition was a few meters or less. Within such an environment, little change of either sea-level or the crustal conditions could easily expose the area subaerially, and subsequent slight subsidence or rise of sea level could again result in marine conditions.

\section{DISCUSSION}

Shallow-water carbonates from DSDP sites were earlier reported from Site 98 off the Bahama area (Perkins, in Hollister, Ewing et al., 1972). This includes peri-reef, calcite-cemented skeletal limestone, consisting of mollusks, corals, calcareous algae, and echinoderms. A possible rudist fragment was also reported. Micrite envelopes, and completely micritized constituents are also in evidence, and most of the carbonate is completely recrystallized. Although no X-ray analysis was available, the carbonate was suggested to consist of calcite. Precipitation of calcite within pore space and leaching effects are obvious, and the resulting moldic porosity and cementation were attributed to a subaerial 
environment. These carbonates are lower Campanian to upper Santonian, and occur at water depths below 3000 meters. They resemble very much the material described above from Site 384.

The finding of shallow-water rocks from reefal and peri-reefal environments from sites in the western North Atlantic suggests considerable crustal subsidence. Either vertical subsidence due to block faulting and/or isostatic adjustment, or sea-floor spreading where horizontal displacement is paralleled by a lowering of the sea floor may be responsible for the situation. According to the spreading hypothesis, the deepest occurrences of drowned reefs and associated environments should be situated at or close to the margins of the present ocean.

The areal distribution of mid-Cretaceous coral-rudist reefs compiled by Douglas et al. (1973) reflects a rather narrow belt situated at present-day Mediterranean latitudes. The carbonates of Site 384 fit very well into this east-west belt.

The present DSDP results do not indicate drowned reefs in central parts of the Atlantic Ocean but the sites mentioned encountered shallow-water carbonates at its western margin. This refers also to the as yet unpublished results of Leg 44. Since some shallow-water carbonates are formed at the present Mid-Atlantic Ridge it may be assumed that the Cretaceous reefs were also formed at or close to the ridge crest at that time. This makes subsidence following sea-floor spreading a probable mechanism to explain the present situation of the shallow-water carbonates in the deep drill holes. A more detailed discussion of the subsidence history of the $J$-Anomaly Ridge and the shallow-water carbonates is given by Tucholke and Vogt (this volume).

\section{ACKNOWLEDGMENTS}

This work was supported by the Deutsche Forschungsgemeinschaft.

\section{REFERENCES}

Bathurst, R. G. C., 1966. Boring algae, micrite envelopes and lithification of molluscan biosparites, Geol. J., v. 5, p. 1532 .

1975. Carbonate sediments and their diagenesis. Developm. Sedimentol., v. 12, Amsterdam (Elsevier).

Dansgaard, W., 1964. Stable isotopes in precipitation. Tellus, v. 16, p. 436.

Douglas, R. G., Moullarde, M., and Nairn, A. E. M., 1973. Causes and consequences of drift in the South Atlantic. In Tarling, D. H. and Runcorn, S. K. (Eds.), Implications of continental drift to the earth sciences: London (Academic Press), p. 517-537.

Folk, R. L., 1962. Spectral subdivision of limestone types. In Ham, W. E. (Ed.), Classification of carbonate rocks-A symposium, Am. Assoc. Petrol. Geol. Mem. 1, p. 62-84.

Ginsburg, R. N., 1964. South Florida carbonate sediments. In Guidebook for Field Trip No. 1. Geol. Soc. Am., Convention 1964, New York (Geol. Soc. Am.).

Griffith, L. S., Pitcher, M. G., and Rice, G. W., 1969. Quantitative environmental analysis of a Lower Cretaceous reef complex. In Friedman, G. M. (Ed.), Depositional environments in carbonate rocks, Soc. Econ. Paleontol. Mineral. Spec. Publ. 14, p. 120-138.

Hollister, C. D., Ewing, J. I., et al., 1972. Initial Reports of the Deep Sea Drilling Project, v. 11: Washington (U.S. Government Printing Office), p. 9-16.

Rey, M. J., 1973. Observations sur l'écologie des Orbitolines et des Choffatelles dans le Crétacé inférieur d'Estremadura (Portugal), C.R. Acad. Sci. Paris, v. 276, p. $2517-$ 2520 .

Shinn, E. A., 1964. Recent dolomite, Sugarloaf Key. In Guidebook for Field Trip No. 1. Geol. Soc. Am., Convention 1964. New York (Geol. Soc. Am.) pp. 62-67.

Shinn, E. A., Ginsburg, R. N., Lloyd, R. M., 1965. Recent supratidal dolomite from Andros Island, Bahamas. In Pray, L. C. and Murray, R. C. (Eds.), Dolomitization and limestone diagenesis: a symposium, Soc. Econ. Paleontol. Mineral. Spec. Publ. 13, p. 112-123. 



\section{PLATE 1}

Figure 1 Carbonate sand, slurry, from the top of the shallow-water carbonate sequence of Site 384, Core 16, Section 1.

Figure 2

Large molds of gastropods (Nerinea?) from biomicrudite, Core 20, Section 1.

Figure 3 Cobbles of limestone (biomicrites and biomicrudites). Note rudist structure at $80 \mathrm{~cm}$ (arrow). Core 20, Section 1.

Figure $4 \quad$ Cobble of biomicrudite with some large molds and also some well preserved skeletal grains. Core 20, Section 1.

Figure $5 \quad$ "Salt and pepper" gravel. The constituents are skeletal grains, entire orbitolines (arrow), and limestone fragments. Core 21, Section 1.

Figure 6

"Salt and pepper" gravel with orbitolines (arrow), overlying light gray limestone with orbitolines in the lower part of the hole. Core 21, Section 1.

Figure 7 Assemblage of skeletal grains from the shallowwater carbonates at Site 384. Note abundance of echinoid spines. 
PLATE 1
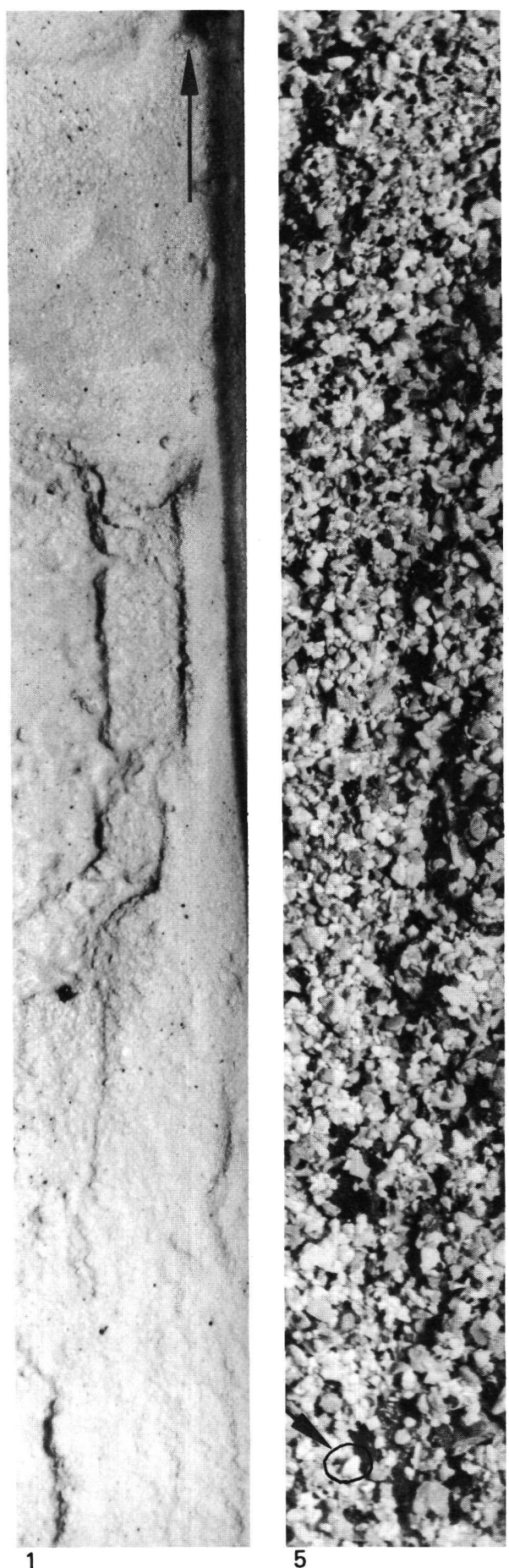

ify

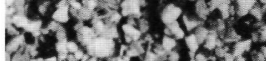

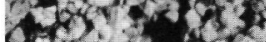

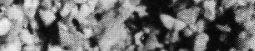

er. $\mathrm{is}^{3}$ ?

$x-x+2 x$

xy 50 , 2

Gise to 5

of $23: 2 x$

stis 3

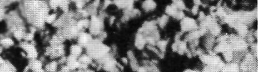

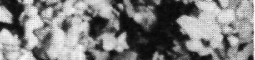

$3 x \cdot 4 a-y^{2}=5$

to 3 ,

1. $4 \mathrm{C}^{2}$.

3 - $x^{4}$.

- 202253

35 tow

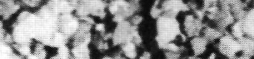

$3 r+2 x-5$

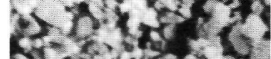

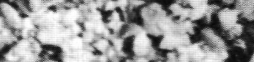

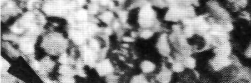

1 (7)

1 is

5
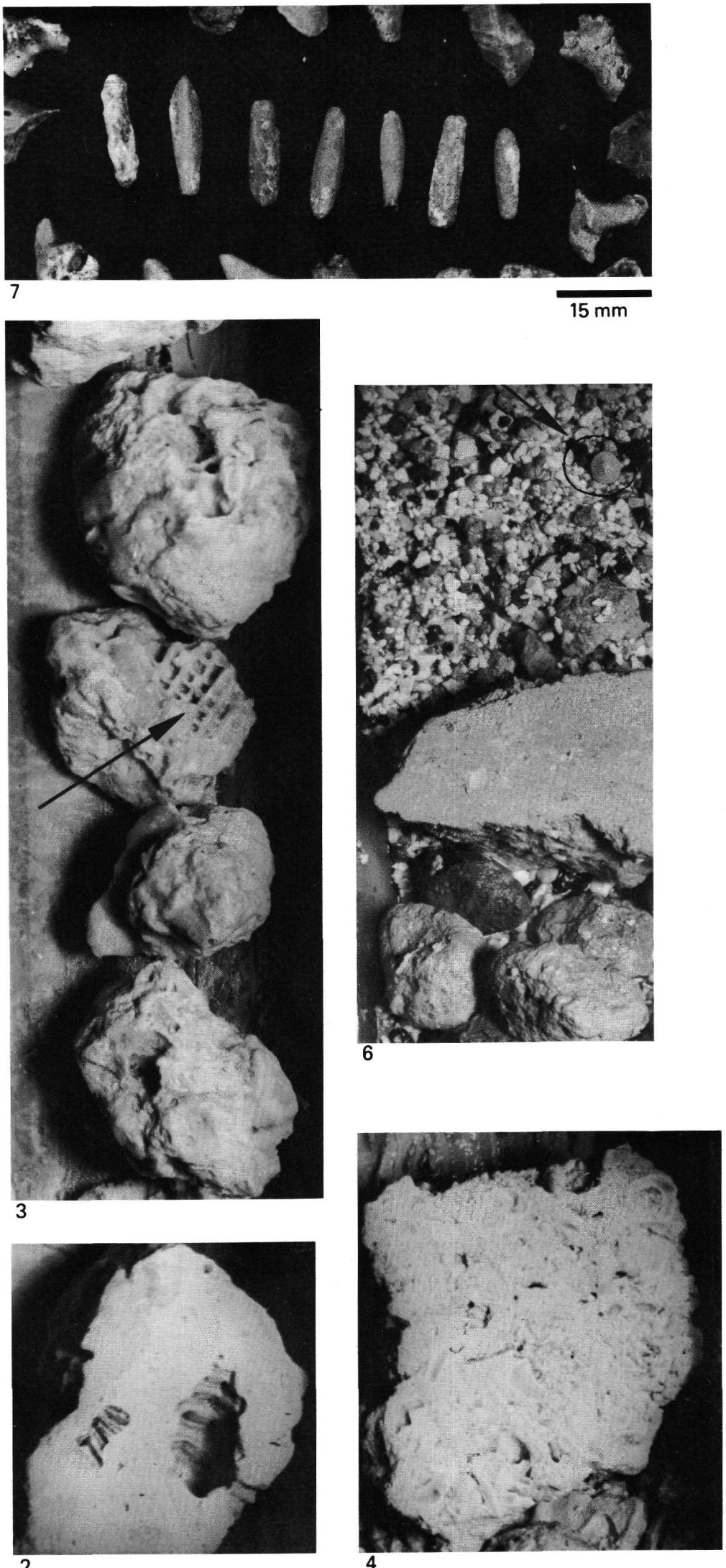


\section{PLATE 2}

Figure $1 \quad$ Bryozoan fragment within biomicrite. Sample 21, CC, 2-4 cm.

Figure 2 Patchy dolomicrite (light gray) within calcitic micrite (dark). Core 20, Section 1, $100 \mathrm{~cm}$. Stained thin section.

Figure 3 Pelmicrite, with few foraminifers. Core 20, Section 1, $100 \mathrm{~cm}$.

Figure 4 Biomicrite. Direct negative print from thin section. Sample 21, CC, 2-4 cm. 
PLATE 2
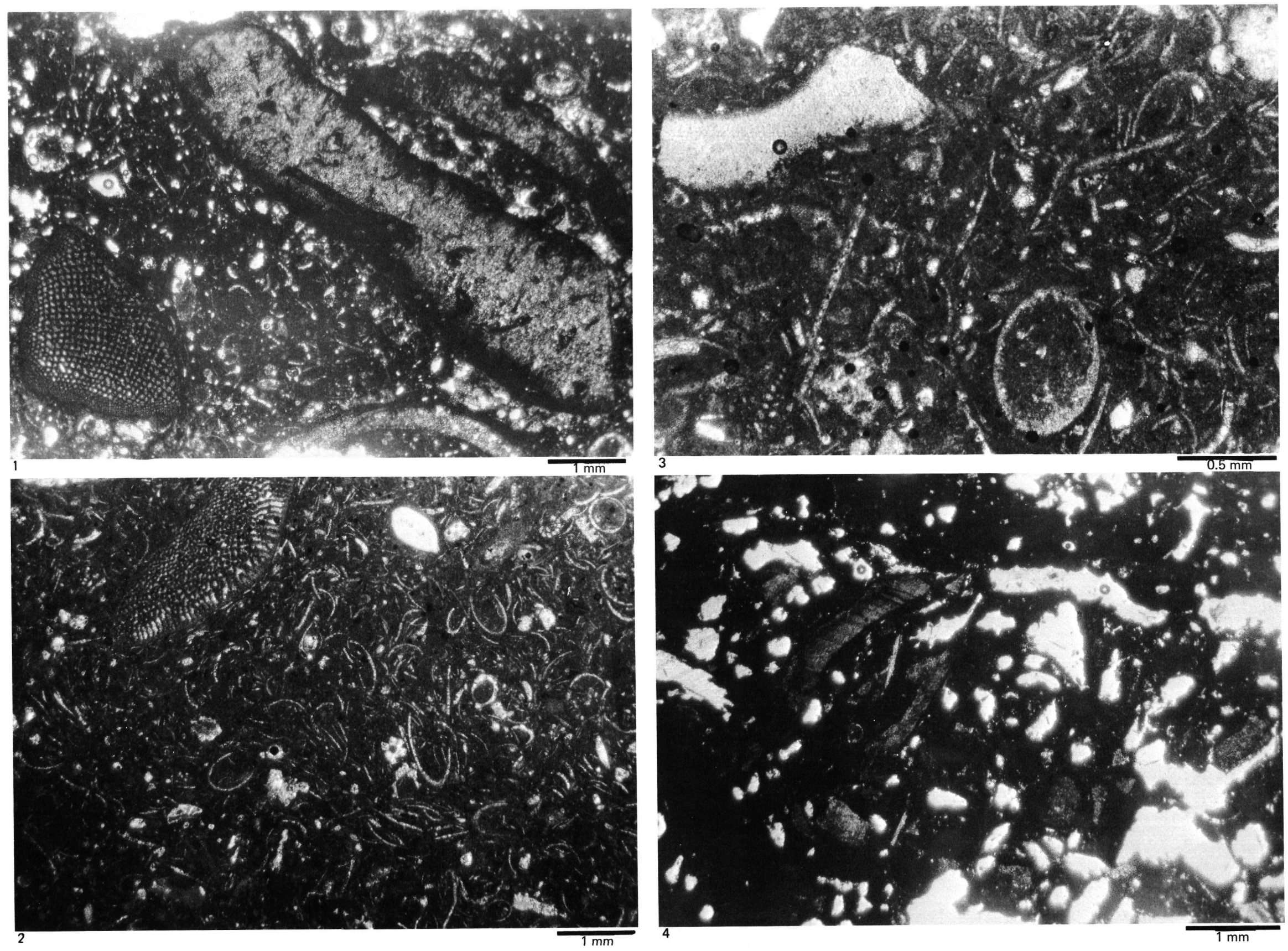


\section{PLATE 3}

Figure 1 Biomicrite, as in Plate 3, Figure 4; another sample from the same part of the core. Note abundance of orbitolines and moldic porosity due to leached skeletals. Sample 21, CC, $2-4 \mathrm{~cm}$.

Figure 2 Biomicrudite, with coral, orbitoline foraminifers, and large, partly preserved mollusk remnant. Note abundant moldic porosity. Negative print from thin section. Half of the picture is dark because of staining. Core 20, Section 1, $100 \mathrm{~cm}$.

Figure 3 Skeletal sand, severely micritized grains. Note that most micritized grains are rounded whereas some preserved mollusk fragments are still angular. Core 16, Section $1,45-46 \mathrm{~cm}$.

Figure 4 Poorly sorted, micritized skeletal sand with some preserved mollusk fragments. Negative print from thin section. Core 16, Section 1, 105-106 cm. 


\section{PLATE 3}
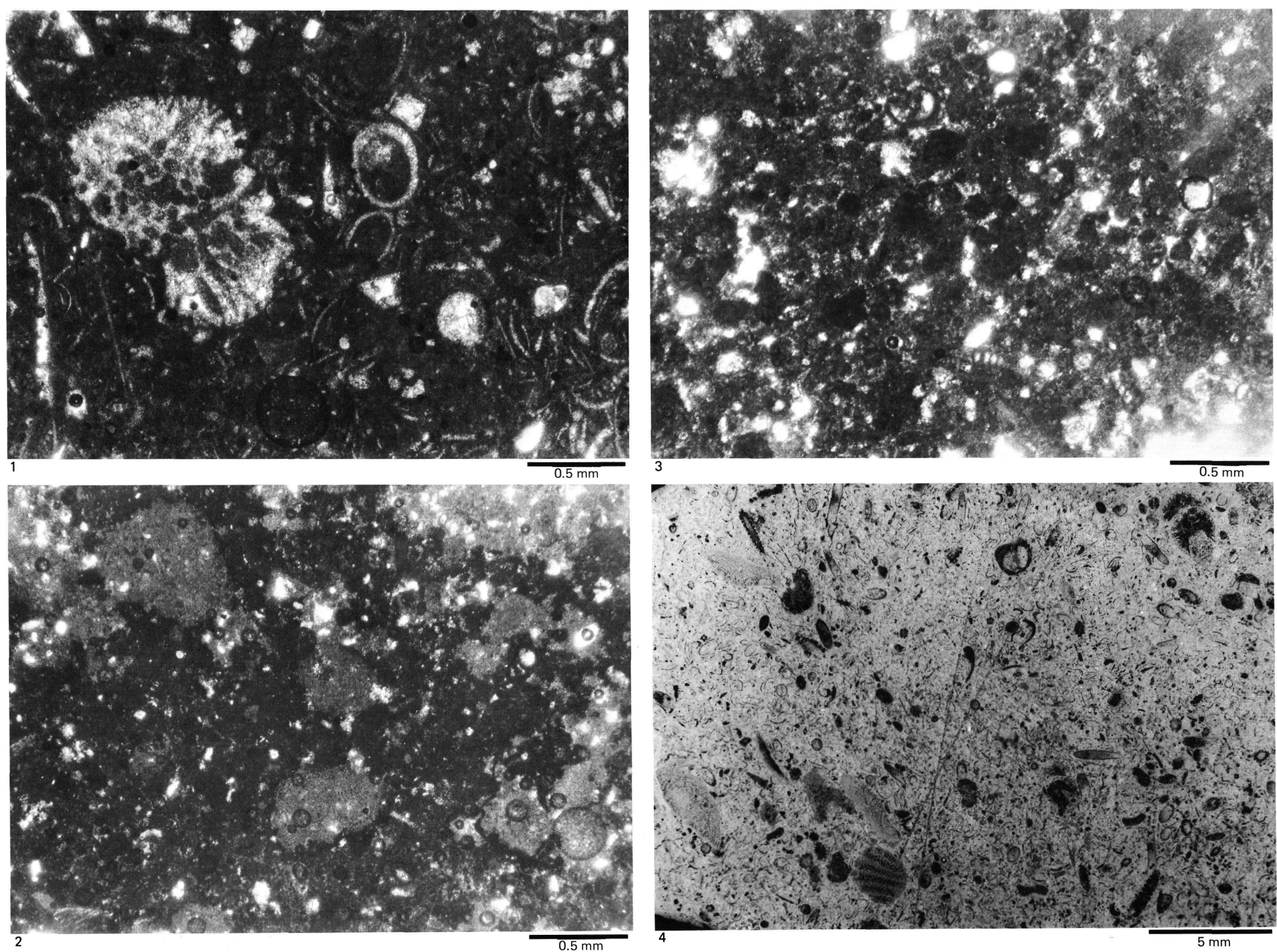


\section{PLATE 4}

Figure 1 Mollusk? remnants with micritic envelope and orbitoline foraminifers. Sample 21, CC, $2-4 \mathrm{~cm}$.

Figure 2 Biomicrite. Mollusks, ostracodes, and scarce foraminifers. The primary shell carbonate is replaced by calcite spar. Sample $21, \mathrm{CC}, 2-4 \mathrm{~cm}$.

Figure 3

Echinoderm fragment preserved within biomicrite. Sample 21, CC, $2-4 \mathrm{~cm}$.

Figure $4 \quad$ Biomicrite with abundant moldic porosity which results from leached formerly aragonitic mollusk (?) shells. Note mollusk fragment with preserved shell structure. Sample 21, CC, $2-4 \mathrm{~cm}$. 
PLATE 4
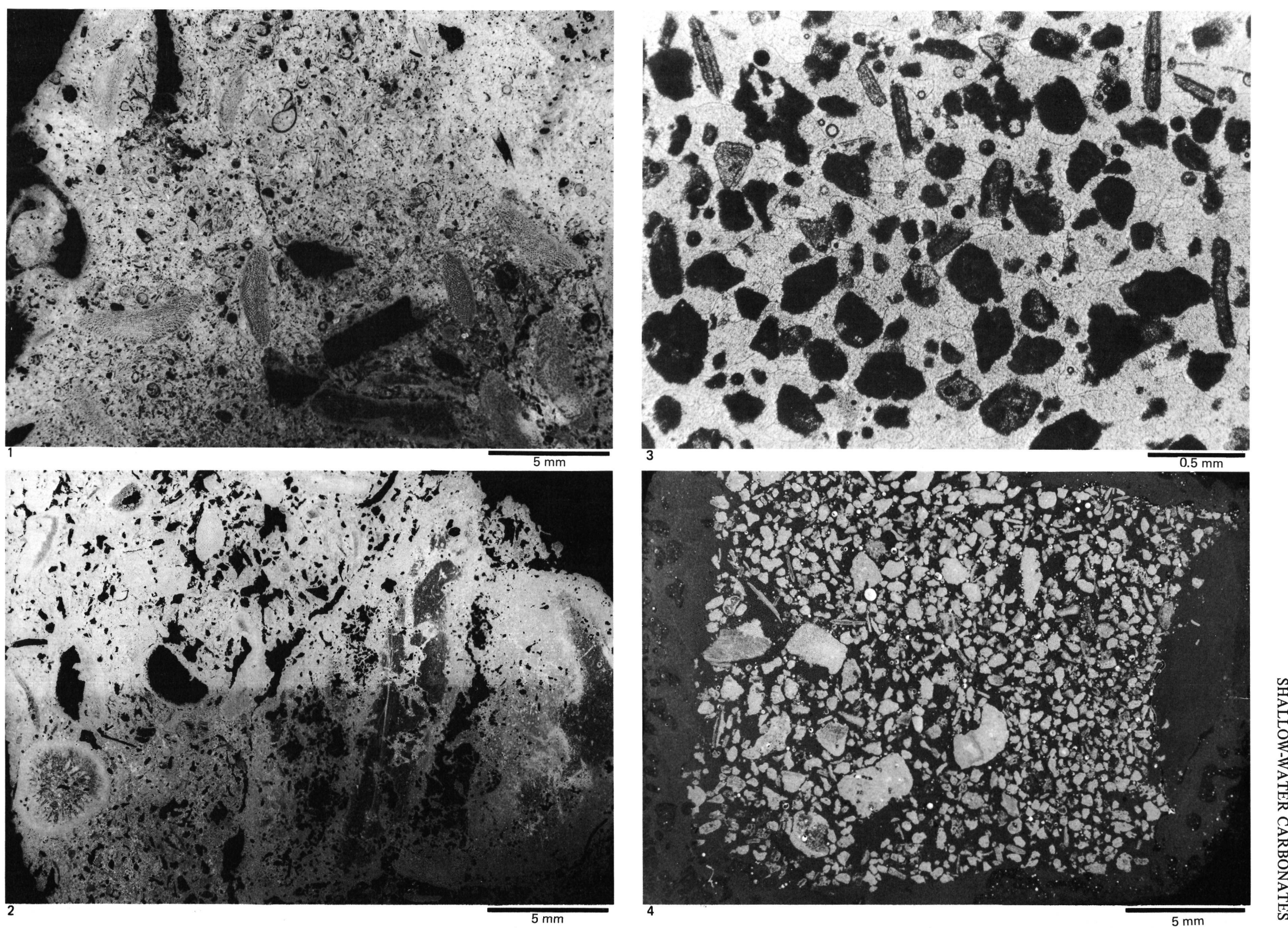


\section{PLATE 5}

Figure 1 Poorly sorted, micritized skeletal sand as in Plate 4, Figure 4, with lump of biomicrite (dark large grain), and echinoid spine (middle of lower part). Core 16, Section 1, 105-106 cm.

Figure 2 Carbonate sand, moderately sorted; micritized grains are better rounded than mollusk fragments, which still have some preserved shell structures. Core 16, Section 1, $45-46 \mathrm{~cm}$.

Figure 3 Biomicrudite pebble with moldic porosity due to leached skeletals, rimmed by red algae (?). Negative print from thin section. Core 16, Section $1,130-150 \mathrm{~cm}$. 

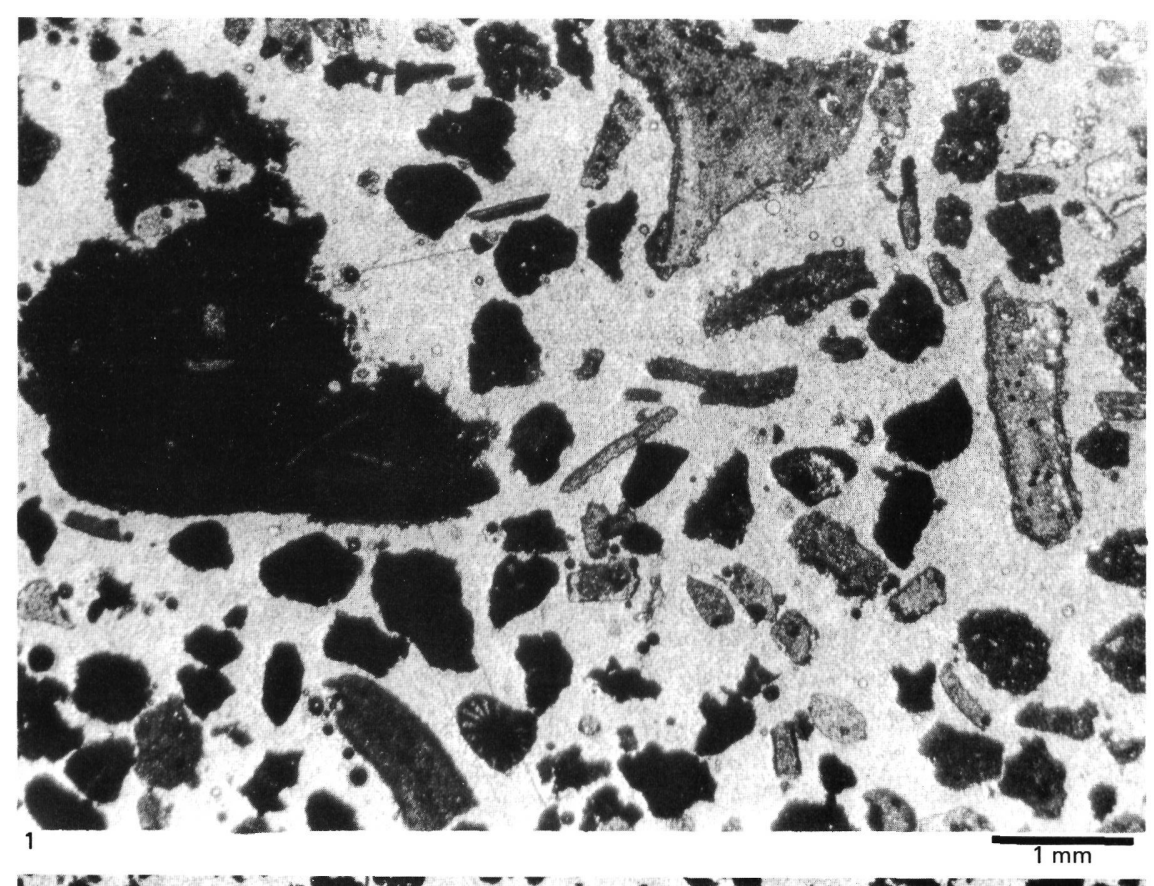

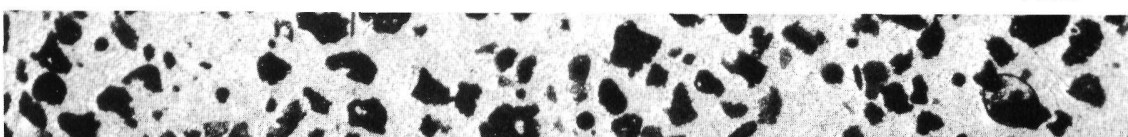
A

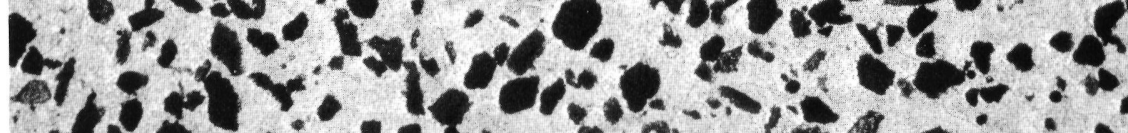

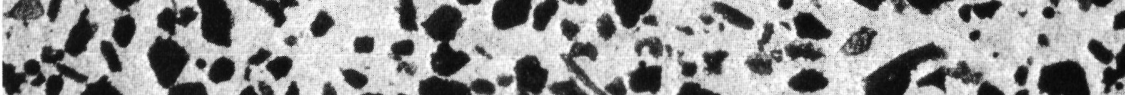

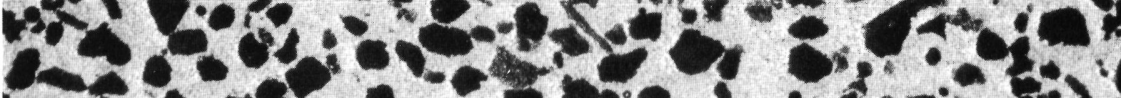

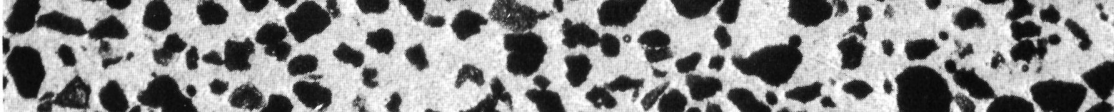

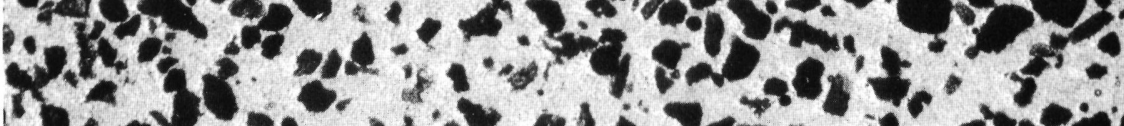

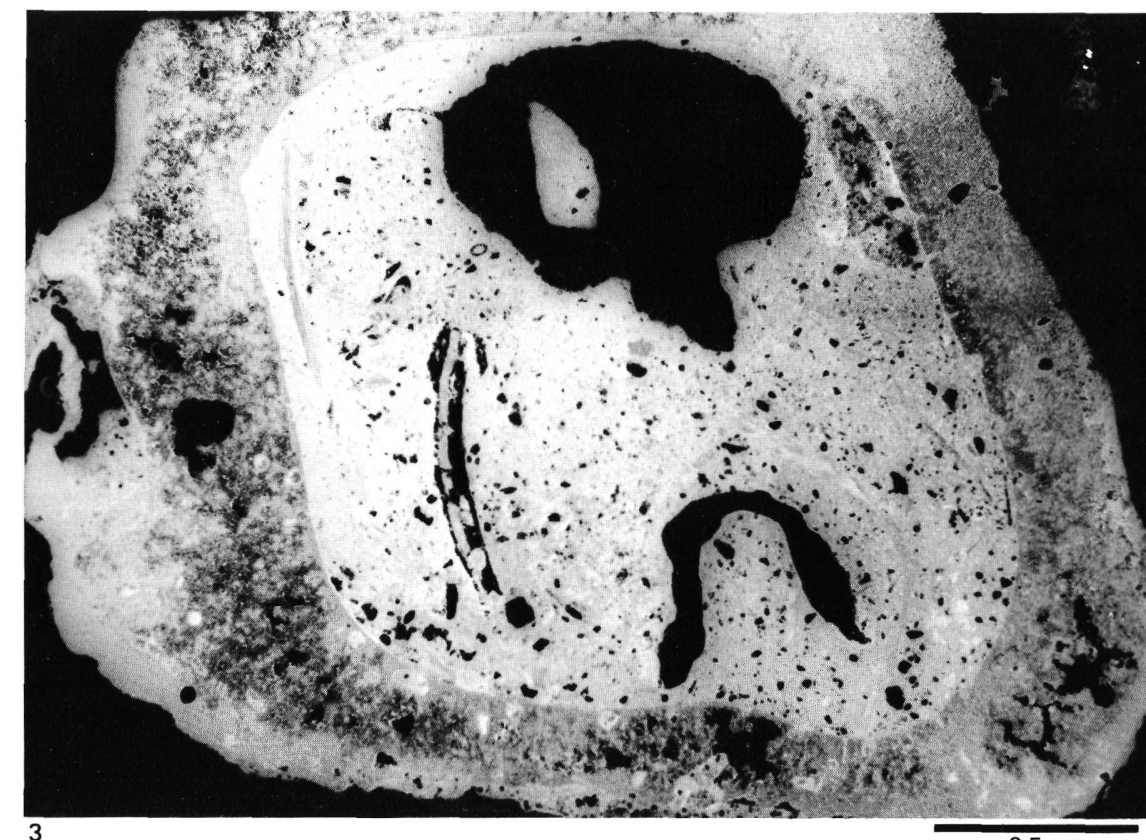

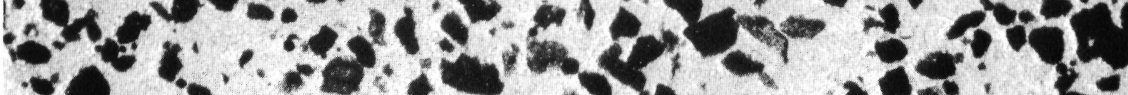

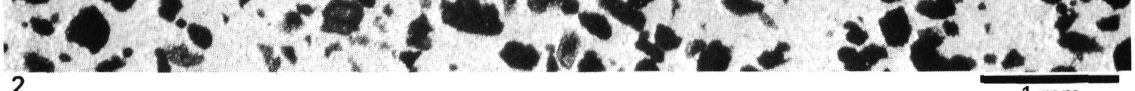

